\title{
PENGARUH PENGATURAN TEMPAT DUDUK TERHADAP MOTIVASI DAN HASIL BELAJAR PADA PEMBELAJARAN TEMATIK INTEGRATIF
}

\author{
Fauzatul Ma'rufah Rohmanurmeta, Muh Farozin \\ SD Muhammadiyah Ponorogo, Universitas Negeri Yogyakarta \\ Email: ayuputri368@yahoo.com,-
}

\begin{abstract}
Abstrak
Penelitian ini bertujuan untuk mendeskripsikan pengaruh pengaturan tempat duduk terhadap motivasi belajar dan hasil belajar pada pembelajaran tematik integratif bagi peserta didik kelas IV SD Muhammadiyah Ponorogo. Penelitian ini merupakan penelitian eksperimen semu, dengan desain pretest-posttest with nonequivalent groups. Pretest dan Posttest digunakan untuk mengukur motivasi dan hasil belajar peserta didik. Hasil penelitian ini menunjukkan bahwa terdapat pengaruh yang positif dan signifikan variasi gaya pengaturan tempat duduk terhadap motivasi dan hasil belajar peserta didik SD Muhammadiyah Ponorogo pada tema cita-citaku. Terbukti dari hasil uji-t dengan signifikansi 0,000 pada kelompok eksperimen I dan eksperimen II, artinya variasi gaya pengaturan tempat duduk mampu meningkatkan motivasi dan hasil belajar tema citacitaku peserta didik SD Muhammadiyah Ponorogo.
\end{abstract}

Kata kunci: pengaturan tempat duduk, motivasi belajar, hasil belajar.

\section{THE EFFECT OF SEATING ARRANGEMENT ON MOTIVATION AND LEARNING OUTCOMES IN AN INTEGRATIVE THEMATIC LEARNING}

\begin{abstract}
This research aimed to describe the effect of seating arrangement on learning motivation and learning outcomes in an integrative thematic learning of the fouth grade students of Muhammadiyah Ponorogo Elementry School. This research was a quasi-experimental with pretest-posttest nonequivalent groups design. A pretest and posttest were used to measure the students motivation and learning outcomes. The result of this study indicates that there is a positive and significant effect of variation style seating arrangement on motivation and learning outcomes in Muhammadiyah Elementry School students. Evident from the results of the test with a significance of 0,000 in the experimental group 1 and experimental group 2, it means that variation style seating arrangement can improve motivation and learning outcomes of student on the theme of my idea of Muhammadiyah Ponorogo Elementry School.
\end{abstract}

Keywords: one or more word(s) or phrase(s), that it's important, spesific, or representative for the article

\section{PENDAHULUAN}

Peraturan pemerintah Nomor 32 Tahun 2013 atau Kurikulum 2013 adalah hasil revisi dari peraturan pemerintah Nomor 19 Tahun 2005 tentang Standar Nasional Pendidikan. Pembelajaran tematik integratif yang terdapat dalam Kurikulum
2013 merupakan hasil revisi oleh pemerintah dari kurikulum sebelumnya yaitu Kurikulum Tingkat Satuan Pendidikan.

Penerapan Kurikulum 2013 disajikan dalam model pembelajaran tematik integratif. Kemendikbud (2013, p.6) menyatakan bahwa pembelajaran tematik 
integratif merupakan pendekatan pembelajaran yang mengintegrasikan berbagai kompetensi dari berbagai mata pelajaran ke dalam berbagai tema. Pembelajaran tematik integratif diharapkan mampu melahirkan peserta didik yang kreatif, cerdas dan inovatif.

Tema cita-citaku merupakan salah satu tema dalam pembelajaran tematik integratif yang menjadi kebutuhan dalam melatih penalaran. Melalui pembelajaran tematik integratif tema cita-citaku diharapkan akan dapat menambah kemampuan dan pengetahuan peserta didik. Tema citacitaku adalah salah satu tema penting pada pembelajaran tematik integratif. Tema ini sebagai tema yang harus ditempuh peserta didik untuk melanjutkan ke tema selanjutnya, karena materinya saling berkaitan dan mencakup kompetensi yang penting untuk dipelajari peserta didik.

Keberhasilan pengajaran pada pembelajaran tematik integratif tergantung pada keberhasilan peserta didik dalam proses pembelajaran, sedangkan keberhasilan peserta didik tidak hanya tergantung pada sarana dan prasarana pendidikan, kurikulum maupun metode. Akan tetapi pengelolaan kelas mempunyai pengaruh terhadap motivasi dan belajar peserta didik. Pengelolaan kelas merupakan unsur yang amat penting dalam proses pembelajaran. Menurut Ahmad (1991, p.2) menjelaskan bahwa pengelolaan kelas dalam proses pembelajaran dilakukan untuk: (1) mewujudkan situasi dan kondisi kelas, (2) menghilangkan berbagai hambatan yang dapat menghalangi terwujudnya interaksi belajar mengajar, (3) menyediakan dan mengatur fasilitas serta perabot belajar, (4) membina dan membimbing sesuai dengan latar belakang sosial, ekonomi, budaya, serta sifat-sifat individu. Oleh sebab itu, pengelolaan kelas dalam pembelajaran perlu dibuat sedemikian rupa untuk mencapai tujuan pembelajaran.

Pengaturan tempat duduk adalah salah satu upaya dalam mengelola kelas.
Terdapat berbagai macam gaya dalam pengaturan tempat duduk. Banyaknya gaya pengaturan tempat duduk yang bisa digunakan menuntut pendidik untuk kreatif dalam memilih gaya pengaturan yang sesuai dengan kondisi kelas dan materi yang akan diberikan. Ketidak sesuaian pemilihan gaya pengaturan tempat duduk terkadang bisa menghambat pemahaman peserta didik terhadap materi pembelajaran.

Para pendidik dalam praktiknya seringkali mengajar dengan pengaturan tempat duduk gaya tradisional yang dilakukan dari masa kemasa. Kurangnya kreatifitas dan inovasi para pendidik dalam mengelola kelas, membuat proses pembelajaran dikelas membosankan bagi peserta didik. Hal ini mengakibatkan rendahnya kesempatan peserta didik untuk berinteraksi secara aktif dalam pembelajaran. Peran pendidik cenderung dominan sehingga partisipasi peserta didik dalam proses pembelajaran rendah dan cenderung kurang tertarik terhadap proses pembelajaran.

Dalam satu kelas peserta didik merupakan makhluk yang berbeda. Perbedaan tersebut dapat dilihat dari aspek kecerdasan, psikologis, dan biologis. Perbedaan tersebut dapat menimbulkan beragamnya sikap peserta didik didalam kelas. Menjadi tugas guru bagaimana menjadikan keanekaragaman peserta didik tersebut dapat diatasi sehingga tujuan pembelajaran dapat tercapai. Hal itu merupakan tugas bagi guru dalam mengelola kelas dengan baik. Keterampilan guru dalam pelaksanaan proses pembelajaran tidak hanya tertuang dalam penguasaan bahan ajar atau penggunaan metode pembelajaran, tetapi proses pembelajaran yang baik akan dipengaruhi pula oleh iklim belajar yang kondusif atau maksimal berkaitan dengan pengaturan orang (peserta didik) dan barang.

Berdasarkan hasil prasurvei pada bulan Maret 2013, terdapat guru yang mengeluh 
karena sukarnya mengelola kelas dengan pengaturan tempat duduk. Pengaturan tempat duduk peserta didik hanya dilakukan dengan gaya tradisional dikarenakan guru belum mengenal berbagai macam gaya tempat duduk peserta didik dalam pembelajaran. Hasil nilai raport kelas IV SD Muhammadiyah Ponorogo semester I tahun ajaran 2013/2014 pada pembelajaran tematik integratif menunjukkan bahwa masih banyak yang belum mencapai ketuntasan minimal yakni 70 , rata-rata dari peserta didik baru mencapai ketuntasan 67. Rendahnya hasil belajar peserta didik juga dibarengi dengan rendahnya motivasi peserta didik dalam mengikuti proses pembelajaran. Hal ini dilihat ketika proses pembelajaran berlangsung, peserta didik tidak fokus terhadap pembelajaran yang ada. Peserta didik lebih senang untuk bermain, saling berbagi cerita antar sesama teman dan terdapat beberapa peserta didik yang suka mengganggu teman yang sedang belajar, sehingga guru harus berkali-kali memperingatkan agar fokus ke pembelajaran.

Mengenai kesenjangan diatas, berbagai upaya penyelesaian perlu dicari dan dilakukan agar kualitas proses pembelajaran dapat dipertahankan dan bahkan ditingkatkan. Salah satu solusi pemecahan masalah persoalan tersebut adalah pengelolaan kelas dengan variasi gaya pengaturan tempat duduk. Variasi gaya pengaturan tempat duduk merupakan suatu cara penyusunan bangku peserta didik yang berfungsi sebagai strategi awal untuk mengatur perilaku peserta didik sesuai yang diinginkan. Pengaturan dilakukan dengan variasi gaya yang berbeda pada setiap pembelajaran. Gaya yang digunakan selama pembelajaran tematik integratif tema cita-citaku adalah gaya berhadap-hadapan (face to face style), gaya chevron (chevron style), gaya kelompok (cluster style), gaya seminar (seminar style), dan gaya konferensi (conference style). Pemilihan gaya disesuaikan dengan kon- disi lapangan dari hasil prasurvei.

Keunggulan variasi gaya pengaturan tempat duduk adalah membantu mencegah masalah akademis dan emosional, serta dapat menyatukan peserta didik dari latar belakang yang berbeda. Kelas yang dikelola dengan variasi gaya pengaturan tempat duduk membuat peserta didik tetap sibuk dengan tugas yang aktif dan menantang, melakukan aktifitas yang membuat peserta didik menjadi terpikat dan termotivasi untuk belajar serta menetapkan peraturan yang jelas yang harus diterima oleh peserta didik. Bila dibandingkan pengaturan tempat duduk gaya tradisional, tentu variasi gaya pengaturan tempat duduk lebih menarik dan menyenangkan bagi peserta didik.

Mengingat terbatasnya waktu, tenaga dan biaya maka diperlukan adanya pembatasan masalah untuk menyederhanakan dan menyempitkan ruang lingkup pembahasan penelitian ini. Permasalahan yang dikaji terpusat pada pokok permasalahan motivasi belajar peserta didik, hasil belajar peserta didik, dan pengelolaan kelas dengan pengaturan tempat duduk yaitu berupa variasi gaya pengaturan tempat duduk dan pengaturan tempat duduk gaya tradisional pada pembelajaran tematik integratif. Disebabkan karena keterbatasan waktu dan luasnya materi pada pembelajaran tematik integratif, maka penelitian ini dibatasi pada tema cita-citaku. Penelitian ini bertujuan untuk mengetahui pengaruh variasi gaya pengaturan tempat duduk yang meliputi face to face style, cheoron style, cluster style, seminar style, dan conference style dalam pembelajaran tematik integratif tema cita-citaku terhadap peningkatan motivasi dan hasil belajar peserta didik kelas IV SD Muhammadiyah Ponorogo.

Dalam penelitian ini definisi operasional untuk pengaturan tempat duduk merupakan suatu cara yang dilakukan dalam rangka mengatur tempat duduk peserta didik yang berfungsi sebagai 
strategi untuk mendorong perilaku peserta didik sesuai yang diharapkan. Pengaturan tempat duduk yang digunakan dalam penelitian ini yakni variasi gaya pengaturan tempat duduk dan pengaturan tempat duduk gaya tradisional. Variasi gaya pengaturan tempat duduk merupakan suatu bentuk pengelolaan kelas dengan mengatur bangku peserta didik secara bervariasi pada setiap pembelajaran. Variasi gaya yang digunakan meliputi gaya berhadap-hadapan (face to face style), gaya chevron (chevron style), gaya kelompok (cluster style), gaya seminar (seminar style) dan gaya konferensi (conference style). Sedangkan pengaturan tempat duduk gaya tradisional merupakan bentuk pengaturan yang sudah menjadi tradisi dari masa kemasa, dengan susunan peserta didik duduk berpasang-pasangan dalam satu meja dengan satu kursi . Tempat duduk pada formasi ini berderet memanjang ke belakang. Motivasi belajar merupakan suatu kekuatan atau dorongan baik dari dalam (intrinsik) maupun dari luar diri individu (ekstrinsik) yang menyebabkannya melakukan kegiatan belajar untuk mencapai tujuan belajar. Sedangkan hasil belajar merupakan kemampuan yang dimiliki seorang peserta didik setelah ia menerima pengalaman belajarnya.

\section{METODE}

Jenis Penelitian

Pendekatan yang digunakan dalam penelitian ini adalah pendekatan kuantitatif, di mana semua data yang diperoleh dapat dirangkum, di analisis dan diolah secara statistik. Jenis penelitian ini merupakan penelitian eksperimen semu. Sesuai dengan pendapat Suryabrata (2013:92) bahwa tujuan penelitian experimental semu adalah untuk memperoleh informasi yang merupakan perkiraan bagi informasi yang dapat diperoleh dengan eksperimen yang sebenarnya dalam keadaan yang tidak memungkinkan untuk mengontrol dan/atau memanipulasikan semua variabel yang relevan. Penelitian eksperimen semu didasarkan atas alasan praktis dan etis (etika). Kadangkala tidak mungkin menempatkan subjek ke dalam kelompok-kelompok. Penelitian ini terdapat tiga kelompok peserta didik, yaitu dua kelompok peserta didik yang diberi perlakuan dengan variasi gaya pengaturan tempat duduk yang meliputi face to face style, cheoron style, cluster style, seminar style, dan conference style sebagai kelompok eksperimen dan satu kelompok peserta didik yang diberi perlakuan dengan pengaturan tempat duduk gaya tradisional sebagai kelompok kontrol.

Waktu dan Tempat Penelitian

Waktu penelitian dilaksanakan pada semester II tahun pelajaran 2013/2014 dimulai pada tanggal 3 Maret sampai 29 Maret 2014 sebanyak 24 pertemuan. Penelitian ini dilakukan di SD Muhammadiyah Ponorogo pada peserta didik kelas IV yang melibatkan dua kelas untuk kelompok eksperimen (IV Al-Amin dan IV Shidiq) dan satu kelas untuk kelompok kontrol (IV Amanah).

\section{Populasi dan Sampel}

Populasi penelitian ini adalah peserta didik Kelas IV SD Muhammadiyah Ponorogo. Jumlah seluruh peserta didik Kelas IV SD Muhammadiyah Ponorogo adalah 166 yang di bagi dalam lima kelas. Teknik pengambilan sampel dilakukan secara random sampling atau acak. Langkah-langkah penentuan sampel adalah menentukan tiga kelas dari lima kelas tersebut yang akan menjadi sampel penelitian dengan. Kelas IV Al Amin ditentukan sebagai kelompok eksperimen I berjumlah 33 peserta didik. Kelas IV Shidiq ditentukan sebagai Eksperimen II berjumlah 34 peserta didik. Sedangkan kelas IV Amanah ditentukan sebagai kelompok kontrol berjumlah 33 peserta didik. 
Desain Penelitian

Penelitian ini menggunakan pretestposttest with nonequivalent groups. Desain penelitian dengan memberikan pretest sebelum pembelajaran dan posttest sesudah pembelajaran pada masing-masing kelompok. Menurut Mertler \& Charles (2005:324) desain ini lebih kuat karena dilakukan pretest untuk membangun ekuivalensi antar kelompok.

\section{Teknik Analisis Data}

Teknik analisis data tentang motivasi dan hasil belajar menggunakan analisis deskriptif dan analisis inferensial. Analisis deskriptif digunakan untuk menggambarkan kondisi peserta didik terhadap motivasi dan hasil belajar baik sebelum maupun sesudah pembelajaran pada ketiga kelas yaitu kelompok eksperimen I, eksperimen II dan kelompok kontrol. Data disajikan dalam bentuk tabel (mean, median, modus, standar deviasi, varian, nilai minimum, nilai maksimum, dan sum) dan histogram sehingga mudah dipahami. Perhitungan analisis deskriptif dilakukan dengan bantuan SPSS 17.00 for windows. Sedangkan analisis inferensial digunakan untuk pengujian hipotesis mengenai pengaruh motivasi dan hasil belajar peserta didik pada kelompok dengan variasi gaya pengaturan tempat duduk dan pengaturan tempat duduk gaya tradisional. Pengujian pengaruh tersebut digunakan uji-t. Sebelum dilakukan pengujian tersebut, terlebih dahulu dilakukan uji asumsi sebagai dasar pengujian independent $t$, uji asumsi yang dimaksud adalah uji normalitas dan uji homogenitas. Uji normalitas dilakukan untuk mengetahui apakah data setiap variabel penelitian yang dianalisis membentuk distribusi normal. Dalam penelitian ini uji normalitas menggunakan metode kolmogorof-smirnov. Sedangkan uji homogenitas digunakan untuk mengetahui apakah varians sampel yang akan dikomparasikan itu homogen atau tidak. Dalam penelitian ini, uji homogenitas menggunakan uji leve$n e$. Perhitungan analisis inferensial juga dilakukan dengan bantuan SPSS 17.00 for windows.

\section{HASIL DAN PEMBAHASAN}

Deskripsi Hasil Penelitian

Hasil analisis deskriptif motivasi belajar peserta didik terhadap pembelajaran tematik integratif tema cita-citaku dengan variasi gaya pengaturan tempat duduk dan pengaturan tempat duduk gaya tradisional ditunjukkan pada Tabel 1 .

Berdasarkan tabel 1 yang diperjelas pada grafik 1, menunjukkan bahwa sebelum pembelajaran dengan variasi gaya pengaturan tempat duduk pada kelompok eksperimen I ke dalam kriteria sedang sebanyak 29 orang peserta didik dengan $87,88 \%$, dan kriteria rendah sebanyak 4 orang peserta didik dengan $12,12 \%$. Pada Kelompok eksperimen II sebelum pembelajaran dengan variasi gaya pengaturan tempat duduk diperoleh kriteria tinggi sebanyak 3 orang peserta didik dengan

Tabel 1. Distribusi Frekuensi Motivasi Belajar

\begin{tabular}{|c|c|c|c|c|c|c|c|c|c|c|c|c|c|}
\hline \multirow{3}{*}{ No } & \multirow{3}{*}{ Kriteria } & \multicolumn{4}{|c|}{ Eksperimen I } & \multicolumn{4}{|c|}{ Eksperimen II } & \multicolumn{4}{|c|}{ Kontrol } \\
\hline & & \multicolumn{2}{|c|}{ Awal } & \multicolumn{2}{|c|}{ Akhir } & \multicolumn{2}{|c|}{ Awal } & \multicolumn{2}{|c|}{ Akhir } & \multicolumn{2}{|c|}{ Awal } & \multicolumn{2}{|c|}{ Akhir } \\
\hline & & $\mathbf{F}$ & $\%$ & $\mathbf{F}$ & $\%$ & $\mathbf{F}$ & $\%$ & $\mathbf{F}$ & $\%$ & $F$ & $\%$ & $\mathbf{F}$ & $\%$ \\
\hline 1. & Sangat Tinggi & & & 33 & 100 & & & 34 & 100 & & & & \\
\hline 2. & Tinggi & & & & & 3 & 8,82 & & & 1 & 3,03 & 8 & 24,24 \\
\hline 3. & Sedang & 29 & 87,88 & & & 21 & 61,76 & & & 22 & 66,67 & 22 & 66,67 \\
\hline 4. & Rendah & 4 & 12,12 & & & 10 & 29,41 & & & 8 & 24,24 & 3 & 9,09 \\
\hline \multirow[t]{2}{*}{5.} & Sangat Rendah & & & & & & & & & 2 & 6,06 & & \\
\hline & Jumlah & 33 & & 33 & 100 & 34 & 100 & 34 & 100 & 33 & 100 & & \\
\hline
\end{tabular}

JURNAL PENELITIAN ILMU PENDIDIKAN, Volume 9, Nomor 1, Maret 2016 
$8,82 \%$, kriteria sedang sebanyak 21 dengan $61,76 \%$, dan kriteria rendah sebanyak 10 orang peserta didik dengan $29,41 \%$. Sedangkan pada kelompok kontrol sebelum pembelajaran dengan pengaturan tempat duduk gaya tradisional diperoleh motivasi belajar peserta didik kriteria tinggi sebanyak 1 orang peserta didik dengan $3,03 \%$, kriteria sedang sebanyak 22 dengan $66,67 \%$, , kriteria rendah sebanyak 8 orang peserta didik dengan kriteria $24,24 \%$, dan kriteria sangat rendah sebanyak 2 orang peserta didik dengan 6,06\%.

Kelompok eksperimen I sesudah pembelajaran dengan variasi gaya pengaturan tempat duduk diperoleh kriteria sangat tinggi sebanyak 33 orang peserta didik dengan persentase sebesar $100 \%$. Kelompok Eksperimen II sesudah pembelajaran dengan variasi gaya pengaturan tempat duduk diperoleh kriteria sangat tinggi sebanyak 34 orang peserta didik dengan persentase sebesar $100 \%$. Sedangkan pada kelompok kontrol sesudah pembelajaran dengan pengaturan tempat duduk gaya tradisional diperoleh kriteria tinggi sebanyak 8 orang peserta didik dengan persentase sebesar $24,24 \%$, kriteria sedang sebanyak 22 orang peserta didik dengan persentase sebesar $66,67 \%$, dan kriteria rendah sebanyak 3 orang peserta didik dengan persentase sebesar $9,09 \%$.

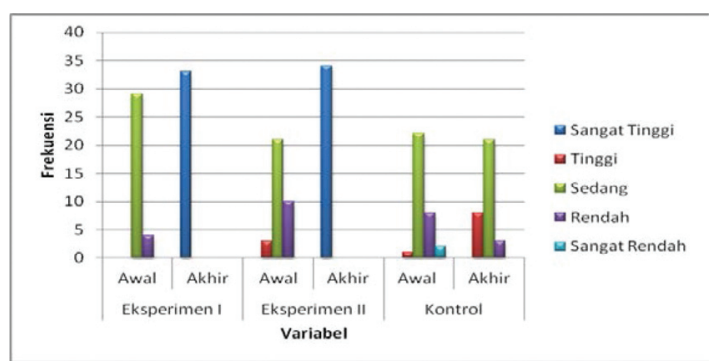

Grafik 1. Perbandingan Motivasi Belajar Peserta Didik

Pre-test merupakan tes kemampuan peserta didik dalam memahami konsep yang diberikan kepada kelompok eksperimen dan kelompok kontrol sebelum perco- baan dilaksanakan. Tes awal ini bertujuan untuk mengetahui kemampuan awal peserta didik pada pembelajaran tematik integratif tema cita-citaku. Data nilai pretest untuk kelompok kontrol di tunjukkan pada grafik 2 berikut ini.

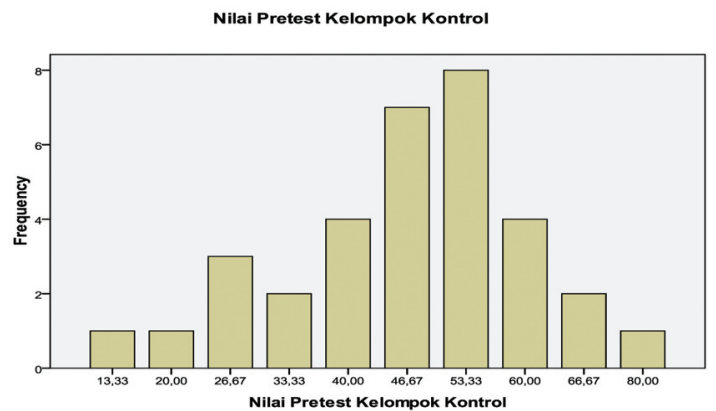

Grafik 2. Nilai Pre-test Kelompok Kontrol

Berdasarkan grafik 2 menunjukkan bahwa nilai 13,33 diperoleh oleh 1 peserta didik, nilai 20,00 diperoleh oleh 1 peserta didik, nilai 26,67 diperoleh oleh 3 peserta didik, nilai 33,33 diperoleh oleh 2 peserta didik, nilai 40,00 diperoleh oleh 4 peserta didik, nilai 46,67 diperoleh oleh 7 peserta didik, nilai 53,33 diperoleh oleh 8 peserta didik, nilai 60,00 diperoleh oleh 4 peserta didik, nilai 66,67 diperoleh oleh 2 peserta didik, dan nilai 80.00 diperoleh oleh 1 peserta didik. Data nilai pre-test kelompok eksperimen I (kelas Al-Amin) ditunjukkan pada grafik 3 berikut ini.

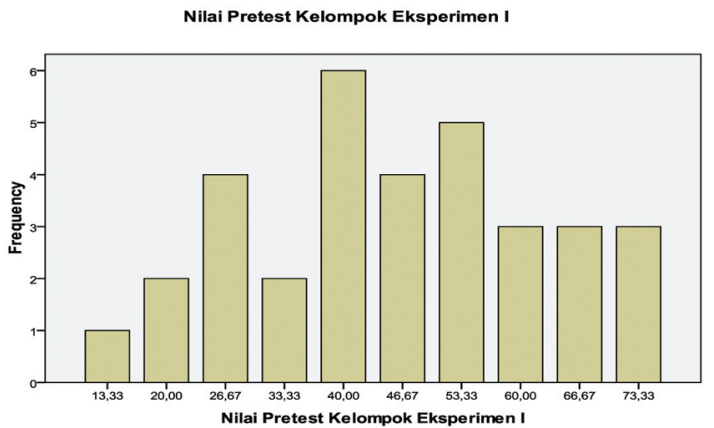

Grafik 3. Nilai Pre-test kelompok eksperimen I

Berdasarkan grafik 3 diatas menunjukkan bahwa nilai 13,33 diperoleh oleh 1 peserta didik, nilai 20,00 diperoleh oleh 2 
peserta didik, nilai 26,67 diperoleh oleh 4 peserta didik, nilai 33,33 diperoleh oleh 2 peserta didik, nilai 40,00 diperoleh oleh 6 peserta didik, nilai 46,67 diperoleh oleh 4 peserta didik, nilai 53,33 diperoleh oleh 5 peserta didik, nilai 60,00 diperoleh oleh 3 peserta didik, nilai 66,67 diperoleh oleh 3 peserta didik, dan nilai 73,33 diperoleh 3 peserta didik. Data nilai pre-test kelompok eksperimen II (kelas Shidiq) ditunjukkan pada grafik 4 berikut ini.

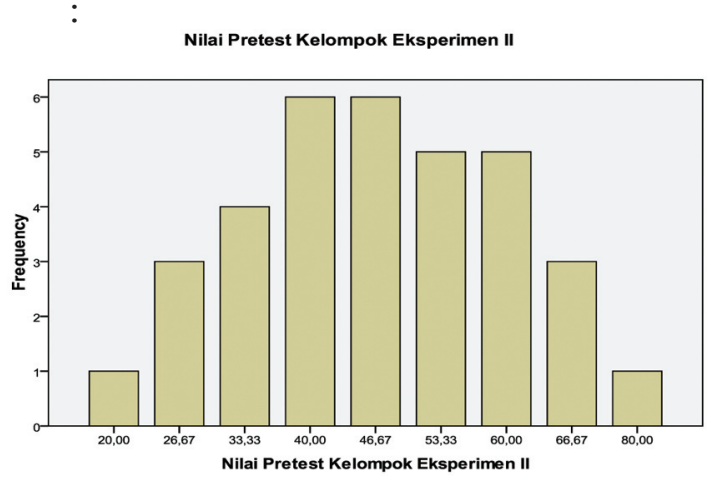

Grafik 4. Nilai pre-test kelompok eksperimen II

Berdasarkan grafik 4 diatas menunjukkan bahwa nilai 20,00 diperoleh oleh 1 peserta didik, nilai 26,67 diperoleh oleh 3 peserta didik, nilai 33,33 diperoleh oleh 4 peserta didik, nilai 33,33 diperoleh oleh 4 peserta didik, nilai 40,00 diperoleh oleh 6 peserta didik, nilai 46,67 diperoleh oleh 6 peserta didik, nilai 53,33 diperoleh oleh 5 peserta didik, nilai 60,00 diperoleh oleh 5 peserta didik, nilai 66,67 diperoleh oleh 3 peserta didik, dan nilai 80,00 diperoleh 1 peserta didik.

Post-test merupakan tes kemampuan peserta didik dalam memahami konsep yang diberikan kepada ketiga kelompok setelah percobaan dilaksanakan. Tes akhir ini bertujuan untuk mengetahui hasil belajar peserta didik pada pembelajaran tematik integratif tema cita-citaku. Data nilai post-test kelompok kontrol, ditunjukkan pada grafik 5 berikut ini.

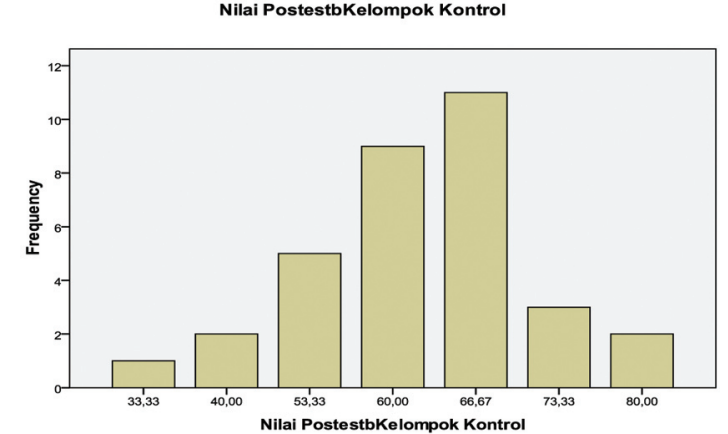

Grafik 5. Nilai Post-test kelompok kontrol

Berdasarkan grafik 5 diatas menunjukkan bahwa nilai 33,33 diperoleh oleh 1 peserta didik, nilai 40,00 diperoleh oleh 2 peserta didik, nilai 53,33 diperoleh oleh 5 peserta didik, nilai 60,00 diperoleh oleh 7 peserta didik, nilai 66,67 diperoleh oleh 11 peserta didik, nilai 73,33 diperoleh oleh 3 peserta didik, nilai 80,00 diperoleh oleh 2 peserta didik. Data pada kelompok eksperimen I ditunjukkan pada grafik 6 berikut:

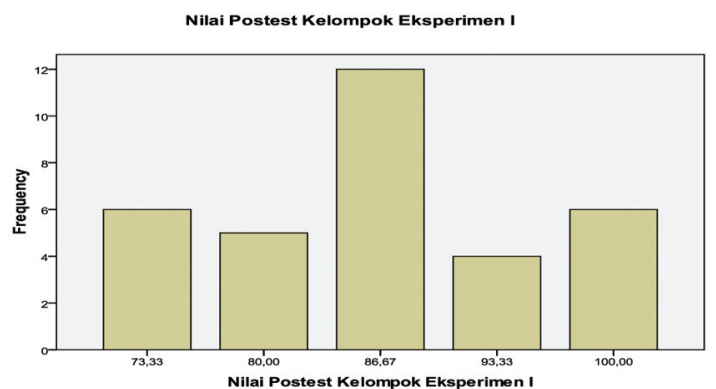

Grafik 6. Nilai Post-test kelompok eksperimen I

Berdasarkan grafik 6 diatas menunjukkan bahwa nilai 73,33 diperoleh oleh 6 peserta didik, nilai 80,00 diperoleh oleh 5 peserta didik, nilai 86,67 diperoleh oleh 12 peserta didik, nilai 93,33 diperoleh oleh 4 peserta didik, nilai 100,00 diperoleh oleh 6 peserta didik. Data pada kelompok eksperimen II ditunjukkan pada grafik 7 berikut. 


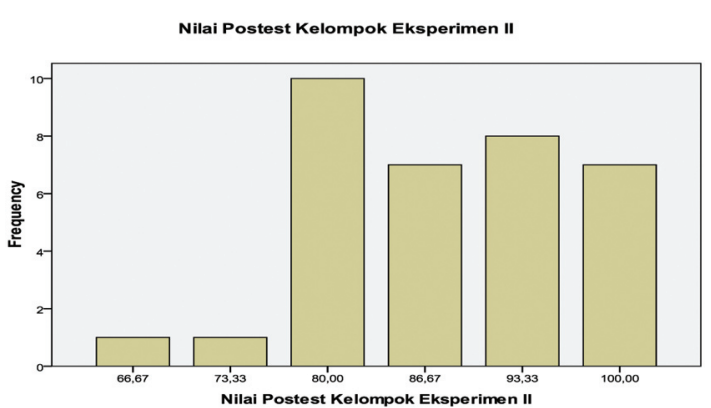

Grafik 7. Nilai Post-test kelompok eksperimen II

Berdasarkan grafik 7 diatas menunjukkan bahwa nilai 66,67 diperoleh oleh 1 peserta didik, nilai 73,33 diperoleh oleh 1 peserta didik, nilai 80,00 diperoleh oleh 10 peserta didik, nilai 86,67 diperoleh oleh 7 peserta didik, nilai 93,33 diperoleh oleh 8 peserta didik, dan nilai 100,00 diperoleh oleh 7 peserta didik.

Uji Persyaratan Statistik Inferensial

Sebelum analisis inferensial dilakukan, perlu uji persyaratan yang meliputi uji normalitas dan uji homogenitas variansi dari masing-masing sampel. Uji normalitas dilakukan untuk mengetahui apakah data setiap variabel penelitian yang akan dianalisis membentuk distribusi normal atau tidak. Berdasarkan hasil output SPSS didapatkan nilai Asymp. Sig. (2-tailed) dengan uji normalitas untuk hasil belajar awal (pretest) baik kelompok eksperimen I, eksperimen II maupun kontrol dengan perhitungan Kolmogorof-Smirnov masing-masing berturut-turut adalah 0,916, 0,831 dan 0,358 . Ketiga nilai tersebut lebih besar dari $\alpha=0,05$ sehingga Ho diterima yaitu data hasil belajar awal peserta didik berdistribusi normal. Sedangkan hasil hitungan dengan Kolmogorov-Smirnov untuk hasil belajar akhir (postest) pada kelompok eksperimen I, eksperimen II, dan kontrol masing-masing berturut-turut $0,195,0,265$, dan 0,159. Ketiga nilai tersebut lebih besar dari $\alpha=0,05$ sehingga Ho diterima yaitu data hasil belajar akhir siswa berdistribusi normal.

Uji normalitas untuk motivasi belajar peserta didik sebelum perlakuan dengan perhitungan Kolmogorov-Smirnov pada kelompok eksperimen I, eksperimen II, dan kelompok kontrol masing-masing berturut-turut adalah 0,383, 0,296, 0,250. Ketiga nilai tersebut lebih besar dari $\alpha$ $=0,05$ sehingga Ho diterima yaitu data motivasi belajar peserta didik sebelum perlakuan berdistribusi normal. Sedangkan hasil perhitungan dengan KolmogorovSmirnov untuk motivasi belajar peserta didik setelah perlakuan pada kelompok eksperimen I, eksperimen II, dan kelompok kontrol masing-masing berturut-turut adalah 0,234, 0,498, dan 0,587. Ketiga nilai tersebut lebih besar dari $\alpha=0,05$ sehingga Ho diterima yaitu data motivasi belajar peserta didik setelah perlakuan berdistribusi normal. Untuk lebih jelasnya hasil perhitungan normalitas data dapat dilihat pada Tabel 2.

Uji homogenitas varians digunakan untuk mengetahui apakah sampel yang diambil dari populasi yang akan dikomparasikan memiliki varian yang sama dan tidak menunjukkan perbedaan yang signifikan satu sama lain. Untuk lebih jelasnya dapat dilihat pada Tabel 3.

Tabel 2. Hasil Perhitungan Normalitas Data

\begin{tabular}{llcccc}
\hline \multirow{2}{*}{ No } & \multirow{2}{*}{ Aspek } & \multicolumn{3}{c}{ Kolmogorof-Smirnov } & \multirow{2}{*}{ Kriteria } \\
\cline { 3 - 5 } & & Eksperimen I & Eksperimen II & Kontrol & \\
\hline 1 & Hasil belajar awal (pretest) & 0,916 & 0,831 & 0,358 & Berdistribusi normal \\
2 & Hasil belajar akhir (posttest) & 0,195 & 0,265 & 0,159 & Berdistribusi normal \\
3 & Motivasi belajar peserta & 0,383 & 0,296 & 0,250 & Berdistribusi normal \\
& didik sebelum perlakuan & & & & \\
4 & Motivasi belajar peserta & 0,234 & 0,498 & 0,587 & Berdistribusi normal \\
& didik setelah perlakuan & & & & \\
\hline
\end{tabular}

Pengaruh Pengaturan Tempat Duduk terhadap Motivasi dan Hasil Belajar ... 
Tabel 3. Uji Homogenitas Variansi Hasil Belajar

\begin{tabular}{cccccc}
\hline Variabel & Kelas & Signifikansi & A & Hasil & Keterangan \\
\hline Hasil belajar berdasarkan & Eksperimen I & 0,671 & 0,05 & Sig $>\alpha$ & Homogen \\
kelompok control & Eksperimen II & 0,588 & 0,05 & Sig $>\alpha$ & Homogen \\
\hline
\end{tabular}

Tabel 4. Uji Homogenitas Variansi Motivasi Belajar

\begin{tabular}{cccccc}
\hline Variabel & Kelas & Signifikansi & A & Hasil & Keterangan \\
\hline Motivasi Belajar berdasarkan & Eksperimen I & 0,489 & 0,05 & Sig $>\alpha$ & Homogen \\
kelompok control & Eksperimen II & 0,739 & 0,05 & Sig $>\alpha$ & Homogen \\
\hline
\end{tabular}

Tabel 5. Hasil Aanalisis Independent $t$ Motivasi dan Hasil Belajar

\begin{tabular}{|c|c|c|c|c|}
\hline \multirow{2}{*}{ Variabel yang diukur } & \multicolumn{2}{|c|}{ Rata-rata } & \multirow{2}{*}{ Sig } & \multirow{2}{*}{ Ket } \\
\hline & Kelompok Kontrol & Kelompok Eksperimen I & & \\
\hline Motivasi belajar & 43,70 & 62,85 & 0,000 & Ho ditolak \\
\hline Hasil belajar & 61,62 & 86,46 & 0,000 & Ho ditolak \\
\hline
\end{tabular}

Tabel 6. Hasil Analisis Independent t

\begin{tabular}{|c|c|c|c|c|}
\hline \multirow[t]{2}{*}{ Variabel yang diukur } & \multicolumn{2}{|c|}{ Rata-rata } & \multirow[t]{2}{*}{ Sig } & \multirow[t]{2}{*}{ Ket } \\
\hline & Kelompok Kontrol & Kelompok Eksperimen II & & \\
\hline Motivasi belajar & 43,70 & 61,09 & 0,000 & Ho ditolak \\
\hline Hasil belajar & 61,62 & 88,04 & 0,000 & Ho ditolak \\
\hline
\end{tabular}

Berdasarkan Tabel 3 diketahui bahwa nilai signifikansi variabel hasil belajar sebelum pembelajaran pada kelompok eksperimen I berdasarkan kelompok kontrol 0,671. Dengan demikian karena nilai signifikansi lebih besar dari $\alpha=0,05$ sehingga Ho diterima yaitu varians dua sampel homogen. Perhitungan homogenitas hasil belajar sebelum pembelajaran pada kelompok eksperimen II berdasarkan kelompok kontrol diperoleh nilai signifikansi sebesar 0,588. Dengan demikian karena nilai signifikansinya lebih besar dari $\alpha=$ 0,05 sehingga Ho diterima yaitu varians dua sampel homogen.

Berdasarkan Tabel 4 diketahui bahwa nilai signifikansi variabel motivasi belajar sebelum pembelajaran pada kelompok eksperimen I berdasarkan kelompok kontrol 0,489. Dengan demikian karena nilai signifikansi lebih besar dari $\alpha=0,05$ sehingga Ho diterima yaitu varians dua sampel homogen. Perhitungan homogeni- tas motivasi belajar sebelum pembelajaran pada kelompok eksperimen II berdasarkan kelompok kontrol diperoleh nilai signifikansi sebesar 0,739. Dengan demikian karena nilai signifikansinya lebih besar dari $\alpha=0,05$ sehingga Ho diterima yaitu varians dua sampel homogen.

Uji Hipotesis

Pengambilan keputusan dan penarikan kesimpulan terhadap uji hipotesis dilakukan dengan taraf signifikansi 5\% $(0,05)$. Kriteria yang digunakan adalah Ho ditolak jika sig $<0,05$. Hasil analisis independent $t$ dengan bantuan SPSS 17.0 for windows disajikan pada Tabel 5 .

Berdasarkan Tabel 5, skor sesudah pembelajaran motivasi belajar pada pembelajaran tematik integratif tema citacitaku dengan variasi gaya pengaturan tempat duduk pada kelompok eksperimen I dan pengaturan tempat duduk gaya tradisional pada kelompok kontrol diperoleh 
nilai t-test $(-23,239)$. Rata-rata skor motivasi belajar sesudah pembelajaran dengan variasi gaya pengaturan tempat duduk pada kelompok eksperimen I sebesar 62,85 dan rata-rata skor sesudah pembelajaran dengan pengaturan tempat duduk gaya tradisional pada kelompok kontrol sebesar 43,70. Berdasarkan angka signifikansi memperoleh nilai sig sebesar 0,000 kurang dari 0,05. Hal ini menunjukkan bahwa Ho ditolak dan Ha diterima. Jadi, ada pengaruh positif pengelolaan kelas dengan variasi gaya pengaturan tempat duduk terhadap motivasi belajar pada pembelajaran tematik integratif tema cita-citaku di SD Muhammadiyah Ponorogo.

Skor hasil belajar pada pembelajaran tematik integratif tema cita-citaku dengan variasi gaya pengaturan tempat duduk pada kelompok eksperimen I dan pengaturan tempat duduk gaya tradisional pada kelompok kontrol diperoleh nilai t-test sebesar $(-10,423)$. Skor rata-rata hasil belajar pada pembelajaran tematik integratif tema cita-citaku dengan variasi gaya pengaturan tempat duduk pada kelompok eksperimen I sebesar 86,46 dan skor rata-rata dengan pengaturan tempat duduk gaya tradisional sebesar 61,62. Berdasarkan angka signifikansi memperoleh nilai sig sebesar 0,000 sehingga kurang dari 0,05 hal ini menunjukkan bahwa Ho ditolak dan Ha diterima. Jadi, ada pengaruh positif pengelolaan kelas dengan variasi gaya pengaturan tempat duduk terhadap hasil belajar pada pembelajaran tematik integratif tema cita-citaku di SD Muhammadiyah Ponorogo.

Berdasarkan tabel 6, skor motivasi belajar sesudah pembelajaran pada pembelajaran tematik integratif tema cita-citaku dengan variasi gaya pengaturan tempat duduk pada kelompok eksperimen II dan pengaturan tempat duduk gaya tradisional pada kelompok kontrol diperoleh niai ttest $(-21,08)$. Rata-rata skor motivasi belajar sesudah pembelajaran dengan variasi gaya pengaturan tempat duduk pada kelompok eksperimen II sebesar 61,09 dan rata-rata skor sesudah pembelajaran dengan pengaturan tempat duduk gaya tradisional pada kelompok kontrol sebesar 43,70. Berdasarkan angka signifikansi memperoleh nilai sig sebesar 0,000 kurang dari 0,05. Hal ini menunjukkan bahwa Ho ditolak dan Ha diterima. Jadi ada pengaruh positif pengelolaan kelas dengan variasi gaya pengaturan tempat duduk terhadap motivasi belajar pada pembelajaran tematik integratif tema cita-citaku di SD Muhammadiyah Ponorogo.

Skor hasil belajar sesudah pembelajaran tematik integratif tema cita-citaku dengan variasi gaya pengaturan tempat duduk pada kelompok eksperimen II dan pengaturan tempat duduk gaya tradisional pada kelompok kontrol diperoleh nilai t-test sebesar $(-11,228)$. Skor rata-rata hasil belajar pada pembelajaran tematik integratif tema cita-citaku dengan variasi gaya pengaturan tempat duduk pada kelompok eksperimen II sebesar 88,04 dan skor rata-rata pengaturan tempat duduk gaya tradisional sebesar 61,62 . Berdasarkan angka signifikansi memperoleh nilai sig sebesar 0,000 sehingga kurang dari 0,05 . Hal ini menunjukkan Ho ditolak dan Ha diterima. Jadi, ada pengaruh positif pengelolaan kelas dengan variasi gaya pengaturan tempat duduk terhadap hasil belajar pada pembelajaran tematik integratif tema cita-citaku di SD Muhammadiyah Ponorogo.

Berdasarkan hasil uji t diperoleh nilai sig $0,000<\alpha$. Hal ini berarti terdapat pengaruh positif pengelolaan kelas dengan variasi gaya pengaturan tempat duduk terhadap motivasi belajar pada pembelajaran tematik integratif tema cita-citaku di SD Muhammadiyah Ponorogo. Suasana yang menarik dan menyenangkan dengan adanya Variasi gaya pengaturan tempat duduk mampu memberikan motivasi peserta didik untuk belajar. Motivasi sebagai alat pendorong terjadinya perilaku belajar peserta didik. Hal ini sesuai 
dengan pendapat Sardiman (2012, p.75) bahwa motivasi sebagai keseluruhan daya penggerak dalam diri peserta didik yang menimbulkan kegiatan belajar. Motivasi belajar sebagai kekuatan atau dorongan untuk mencapai tujuan belajar

Terdapat lima unsur utama yang mempengaruhi motivasi belajar peserta didik baik intrinsik maupun ekstrinsik yaitu: peserta didik, guru, materi, pengelolaan kelas, dan lingkungan belajar. Hal ini sesuai dengan pendapat Dimyati \& Mudjiono (1994, p.89) bahwa ada beberapa unsur yang mempengaruhi motivasi belajar, yaitu: 1) kemampuan belajar siswa, 2) upaya guru membelajarkan siswa, 3) materi pembelajaran, 4) kondisi lingkungan belajar siswa, dan 5) pengelolaan kelas yang baik. Peningkatan nilai motivasi belajar pada kelompok peserta didik dengan variasi gaya pengaturan tempat duduk diantaranya dipengaruhi oleh salah satu atau lebih dari lima unsur utama tersebut. Motivasi belajar yang ditimbulkan mampu membuat peserta didik bergairah dalam mengikuti proses pembelajaran.

Variasi gaya pengaturan tempat duduk menjadi salah satu bentuk pengelolaan kelas yang mampu membangkitkan motivasi belajar peserta didik. Ketrampilan pengelolaan kelas yang dilakukan guru mempunyai peran penting dalam meningkatkan motivasi belajar peserta didik. Hal ini sesuai dengan pendapat Usman (2009, p.97) bahwa pengelolaan kelas merupakan prasyarat mutlak bagi tercapainya proses belajar mengajar yang optimal. Kondisi belajar yang optimal dapat dicapai dengan variasi gaya pengaturan tempat duduk untuk menciptakan suasana kelas yang menyenangkan sehingga tujuan pengajaran dapat tercapai.

Variasi gaya pengaturan tempat duduk yang meliputi gaya berhadap-hadapan (face to face style), gaya chevron (chevron style), gaya kelompok (cluster style), gaya seminar (seminar style), dan gaya konferensi (conference style) mampu mencegah berkembangnya masalah-masalah emosional pada siswa. Kelas yang dikelola dengan variasi gaya pengaturan tempat duduk membuat peserta didik tetap sibuk dengan tugas yang aktif dan menantang, melakukan aktivitas yang membuat peserta didik menjadi terpikat dan termotivasi untuk belajar, serta menetapkan peraturan yang jelas yang harus diterima oleh peserta didik.

Sedangkan pengelolaan kelas dengan pengaturan tempat duduk gaya tradisional tidak memberikan pengaruh positif terhadap motivasi belajar pada pembelajaran tematik integratif tema cita-citaku di SD Muhammadiyah Ponorogo. Hal ini dikarenakan dengan adanya satu macam gaya yang digunakan dari masa kemasa membuat peserta didik merasa bosan. Kurangnya kreatifitas yang dilakukan guru dalam mengatur tempat duduk siswa membuat pembelajaran menjadi monoton. Peserta didik tidak memiliki kesempatan untuk berinteraksi secara aktif dalam pembelajaran. Peran pendidik cenderung dominan membuat partisipasi peserta didik rendah dan kurang tertarik terhadap proses pembelajaran, sehingga mengakibatkan motivasi belajar peserta didik rendah.

Terdapat pengaruh positif pengelolaan kelas dengan variasi gaya pengaturan tempat duduk terhadap hasil belajar pada pembelajaran tematik integratif tema citacitaku di SD Muhammadiyah Ponorogo. Hasil belajar peserta didik merupakan hasil dari suatu proses yang didalamnya terlibat sejumlah faktor yang saling mempengaruhinya. Susanto (2013, p.14) menjelaskan bahwa terdapat faktor yang dapat dikatakan hampir sepenuhnya tergantung pada peserta didik. Faktor-faktor itu adalah kecerdasan anak, kesiapan anak, dan bakat anak. Faktor yang sebagian penyebabnya hampir sepenuhnya tergantung pada guru, yaitu: kemampuan (kompetensi), suasana belajar, dan kepribadian guru. Variasi gaya pengaturan tempat duduk sebagai faktor 
dari luar diri peserta didik yang mampu menciptakan lingkungan belajar sesuai dengan tujuan pembelajaran.

Peningkatan motivasi belajar peserta didik dengan adanya variasi gaya pengaturan tempat duduk mengakibatkan hasil belajar juga meningkat. Adanya pengaturan tempat duduk yang bervariasi pada setiap pembelajaran mampu meningkatkan interaksi antar siswa, dan interaksi dengan guru. Peserta didik lebih fokus terhadap proses pembelajaran sehingga hasil belajar meningkat. Hal ini sesuai dengan pendapat Novan Ardy Wiyani (2013, p.132) bahwa perubahan posisi tempat yang bervariasi memiliki banyak manfaat, antara lain: 1) menghindari kejenuhan pada peserta didik dalam belajar, 2) menjadikan fokus belajar peserta didik tetap terjaga, 3) meningkatkan konsentrasi belajar peserta didik, dan 4) memudahkan guru dan peserta didik bergerak dan berinteraksi saat kegiatan belajar dan mengajar didalam kelas. Beberapa manfaat tersebut kelas akan menjadi kondusif sehingga hasil belajar diperoleh secara maksimal.

Variasi gaya pengaturan tempat duduk mampu menyatukan adanya keberagaman peserta didik didalam lingkungan kelas. Lingkungan kelas perlu ditata dengan baik sehingga memungkinkan terjadinya interaksi yang aktif antara peserta didik dengan guru dan antar peserta didik. Pola pengelompokan peserta didik dengan variasi gaya pengaturan tempat duduk berguna untuk menciptakan lingkungan belajar aktif, kreatif, sehingga kegiatan belajar yang penuh kesenangan dan bergairah dapat bertahan dalam waktu yang relatif lama. Sesuai dengan pendapat Mc Leod \& Ruth Reynolds (2004, p.69) menjelaskan bahwa "often there is a need to develop social skills to assist group participations". Maksudnya adalah seringkali ada kebutuhan untuk mengembangkan keterampilan sosial untuk membantu partisipasi peserta didik dalam kelompok. Variasi gaya pengaturan tempat duduk sebagai salah satu alternatif ketrampilan sosial dalam membantu peserta didik bekerja sama dalam kelompok.

Sedangkan pengaturan tempat duduk gaya tradisional tidak memberikan pengaruh yang positif terhadap hasil belajar pada pembelajaran tematik integratif tema cita-citaku di SD Muhammadiyah Ponorogo. Hal ini dikarenakan peserta didik merasa bosan dan jenuh dengan adanya satu macam gaya pengaturan tempat duduk yang digunakan. Kurangnya kreatifitas guru dalam mengelola kelas dengan pengaturan tempat duduk menyebabkan motivasi belajar peserta didik rendah sehingga mengakibatkan rendahnya hasil belajar yang dicapai peserta didik.

\section{PENUTUP}

Simpulan

Variasi gaya pengaturan tempat duduk mampu meningkatkan motivasi belajar pada pembelajaran tematik integratif tema cita-citaku di SD Muhammadiyah Ponorogo. Terbukti dari hasil uji $t$ diperoleh signifikansi 0,000 menunjukkan terdapat pengaruh yang positif variasi gaya pengaturan tempat duduk terhadap motivasi belajar pada pembelajaran tematik integratif tema cita-citaku di SD Muhammadiyah Ponorogo. Variasi gaya pengaturan tempat duduk mampu meningkatkan hasil belajar pada pembelajaran tematik integratif tema cita-citaku di SD Muhammadiyah Ponorogo. Terbukti dari hasil uji t diperoleh signifikansi 0,000 menunjukkan terdapat pengaruh yang positif variasi gaya pengaturan tempat duduk terhadap hasil belajar pada pembelajaran tematik integratif tema cita-citaku di SD Muhammadiyah Ponorogo.

\section{Saran}

Pengelolaan kelas dengan variasi gaya pengaturan tempat duduk hendaknya dilakukan pada pembelajaran tematik integratif. Terbukti pengelolaan kelas dengan variasi gaya pengaturan tempat duduk 
yang meliputi gaya berhadap-hadapan (face to face style), gaya chevron (chevron style), gaya kelompok (cluster style), gaya seminar (seminar style), dan gaya konferensi (conference style) dapat mempengaruhi tingkat motivasi dan hasil belajar peserta didik pada pembelajaran tema cita-citaku secara lebih baik.

Variasi gaya pengaturan tempat duduk dapat dijadikan masukan untuk memfasilitasi dalam fasilitas pembelajaran untuk meningkatkan motivasi dan hasil belajar peserta didik secara lebih baik. Bagi guru diharapkan dapat melaksanakan pengelolaan kelas dengan variasi gaya pengaturan tempat duduk pada tema yang lain seperti tema indahnya negriku, lingkungan tempat tinggalku, indahnya kebersamaan, dll, karena materi tersebut memerlukan pengelolaan kelas dengan variasi gaya pengaturan tempat duduk untuk mempermudah peserta didik memahami konsep pembelajaran tematik integratif.

\section{DAFTAR PUSTAKA}

Kemendikbud. (2013). Kurikulum 2013 Kompetensi Dasar Sekolah Dasar (SD)/ Madrasah Ibtidaiyah (MI). Kementrian Pendidikan dan Kebudayaan.

Rohani, Ahmad, \& Ahmadi, A. (1991). Pengelolaan kelas, Jakarta: Rineka Cipta.

Sardiman. (2012). Interaksi dan motivasi belajar mengajar. Jakarta: Raja Grafindo Persada

Dimyati \& Mudjiono. (1994). Belajar dan pembelajaran. Jakarta: Rineka Cipta.

Mertler, C.A., \& Charles, C.M. (2005). Introduction to educational research $\left(5^{\text {th }} \mathrm{ed}\right)$. Singapore: Pearson.

Usman, M.U. 2009. Menjadi guru profesional. Bandung: PT Remaja Rosdakarya.

Suryabrata, S. (2013). Metode penelitian. Jakarta: Raja Grafindo Persada

Susanto A, (2013). Teori belajar pembelajaran. Jakarta: Kencana Prenada Media Group.

Wiyani, N.A. (2013). Manajemen kelas. Jogjakarta: Ar-ruzz Media

Mc Leod, J.H., \& Reynolds, R. (2004). Planning for learning. Australia: Thomson Social Science Press. 